\title{
JURNAL NUANSA
}

\section{Peran Notaris Dalam Meningkatkan Pengetahuan Hukum Pekerja Seni}

\author{
Meldawati Majid* \\ lrwan Santosa** \\ *Universitas Jayabaya \\ **Universitas Jayabaya
}

\begin{tabular}{l} 
ARTICLE INFO \\
\hline Keywords: \\
Knowledge of the law, \\
deed authentic, notary, artists
\end{tabular}

Corresponding Author: irsan_not®yahoo.co.id

Nuansa Kenotariatan

Volume 1 Nomor 1

Juli-Desember 2015

ISSN. 2477-4103

hh. 25-32

\begin{abstract}
This research aim to realize the deal of the parties concerned, the laws and regulations in force in Indonesia (positive law) to facilitate both theoretical and/or practices. Specialized in this research are find artist in making agreements/contracts have not been in the form of notarial deed (deed authentic). The situation occurs according to internal factors artists include: lack of knowledge about the making of the agreement/ contract, lack of knowledge in the profession of notary authority and position, not a relationship that is conducive to the notary. This research is a normative law (doctrinal) based on secondary data. The research approach used to analyze the problems in this research include: (a)Conceptual approaches; (b) statute approach; and (c) a conceptual approach. Therefore, this result is expected to improve the legal knowledge among artists in person and/or organization, to support the development of Indonesian art world becomes more advances and has a strong competitive edge for artists to make any agreement/contracts with related parties based on a better knowledge of the law.
\end{abstract}

Penelitian ini bertujuan untuk mewujudkan kesepakatan dari pihakpihak terkait, hukum dan peraturan yang berlaku di Indonesia (hukum positij) dalam memfasilitasi baik teoritis dan!atau praktik. Khusus dalam penelitian ini adalah menemukan pekerja seni yang belum membuat perjanjianl kontrak dalam bentuk akta notaris (akta otentik). Situasi ini terjadi menurut faktor internal pekerja seni meliputi: kurangnya pengetahuan tentang pembuatan perjanjianlkontrak, kurangnya pengetahuan dalam profesi otoritas notaris dan posisi,bukan hubungan yang kondusif untuk notaris. Penelitian ini merupakan hukum normatif (doktrinal) berdasarkan data sekunder. Pendekatan penelitian yang digunakan untuk menganalisis masalah dalam penelitian ini meliputi: (a) pendekatan konseptual; (b) pendekatan undang-undang; dan (c) pendekatan konseptual. Oleh karena itu, hasil ini diharapkan dapat meningkatkan pengetahuan hukum di kalangan seniman secara pribadi dan/atau organisasi, untuk mendukung perkembangan seni rupa Indonesia di dunia menjadi lebih kemajuan dan memiliki keunggulan kompetitif yang kuat bagi seniman untuk membuat kesepakatan apapunlkontrak dengan pihak terkait berdasarkan pengetahuan yang lebih baik dari hukum 


\section{Pendahuluan}

Hubungan kerja antara pihak yang melahirkan suatu perjanjian, dalam pelaksanaan tidak tertutup kemungkinan dapat terjadi perselisihan. Masalah timbul di awal, di tengah perjalanan, di akhir waktu, atau setelah pekerja seni melakukan prestasi yang telah disepakati. Hubungan kerja diantara pihak yang terlibat dalam perkembangan dunia seni kemudian melahirkan suatu keadaan simbiosis-mutualism. Dengan kata lain, kerjasama yang terjadi antara dua pihak atau lebih, antar perorangan atau perorangan dengan suatu organisasi berbadan hukum/tidak berbadan hukum, ada juga hubungan kerja dengan antara pekerja seni dengan Negara (lembaga yang mewakili). Bertitik tolak dari latar belakang di atas, penelitian tentang apakah Notaris telah menjadi pihak yang dipilih pekerja seni untuk membantu meningkatkan pengetahuan hukum dalam pembuatan kontrak komersial, kemudian dibuat dalam bentuk akta notaris (akta otentik)?.

Menurut Undang-Undang Jabatan Notaris (UUJN) RI No. 30 Tahun 2004 tentang Jabatan Notaris pada Pasal1 angka (1), menjelaskan yang dimaksud dengan Notaris adalah pejabat umum yang berwenang untuk membuat akta otentik dan kewenangan lainnya sebagaimana dimaksud dalam UndangUndang Jabatan Notaris (UUJN), antara lain Notaris berwenang membuat akta otentik mengenai semua perbuatan, perjanjian, dan ketetapan yang diharuskan oleh peraturan perundang-undangan dan/atau yang dikehendaki oleh yang berkepentingan untuk dinyatakan dalam suatu akta otentik. Kewenangan notaris tersebut merupakan salah satu cara yang dapat dipergunakan menghasilkan memberikan jalan keluar atas persoalan-persoalan hukum antara pekerja seni dengan pengguna jasanya.

Notaris merupakan profesi hukum dan dengan demikian profesi notaris adalah profesi mulia (nobile officium).Disebut sebagai nobile officium dikarenakan profesi notaris sangat erat hubungannya dengan kemanusiaan (Anshori, 2010). Notaris merupakan perpanjangan tangan dari pemerintah dalam hal ini Negara memberikan kepercayaan kepada Notaris untuk menjalankan sebagian urusan atau tugas Negara, khususnya dalam bidang hukum perdata (Dewi dan Diraja, 2011).

Notaris diangkat dalam jabatannya berdasarkan Undang-Undang Jabatan Notaris (UUJN) yang bertanggung jawab sebagai pejabat umum secara perdata atas akta yang dibuatnya (Anshori, 2010). Konstruksi yuridis yang digunakan dalam tanggung jawab perdata terhadap kebenaran materiil terha- dap akta yang dibuat oleh notaris adalah konstruksi perbuatan melawan hukum berdasarkan Pasal1365 KUHPerdata. Melalui konstruksi penjelasan Undang-Undang Jabatan Notaris (UUJN) bahwa Notaris dapat pula dimintai pertanggungjawaban atas kebenaran materiil suatu akta yang dibuatnya hila ternyata Notaris tersebut tidak memberikan akses mengenai suatu hukum tertentu yang berkaitan dengan akta yang dibuatnya sehingga salah satu pihak merasa tertipu atas ketidaktahuannya.

D am pasal 266 KUHPidana, mengenai suatu akta otentik yang di dalamnya seseorang menyuruh memasukkan keterangan palsu ke dalam akta itu tentang hal yang kebenarannya harus dibuktikan oleh akta itu dengan tujuan untuk memakai atau menyuruh orang lain memakai akta itu seolah-olah keterangan itu benar. Pada hakekatnya Notaris selaku Pejabat Umum, hanyalah mengkonstantir atau merelateer atau merekam secara tertulis dan otentilr dari perbuatan hukum pihak-pihak yang berkepentingan, Notaris tidak berada di dalamnya, adalah orang luar, yang melakukan perbuatan hukum itu adalah pihak-pihak yang membuat serta yang terikat dalam dan oleh isi perjanjian, adalah mereka pihak-pihak yang berkepentingan, inisiatif terjadinya pembuatan akta Notaris atau akta otentik itu berada pada pihak-pihak. Oleh karena itu akta Notaris atau akta otentik tidak menjamin bahwa pihak-pihak "berkata benar" tetapi yang dijamin oleh akta otentik adalah pihak-pihak "benar berkata" seperti yang termuat di dalam akta perjanjian mereka (Sjaifurrachman dan Adjie, 2011).

Berdasarkan kewena.'1gan Notaris menurut Pasal15 ayat (2) huruf (e) UUJN: "Notaris berwenang memberikan penyuluhan hukum sehubungan dengan pembuatan akta." Notaris sebagai pejabat umum (openbaar arnbtenaar) yang berwenang membuat akta otentik dapat dibebani tanggung jawab atas perbuatannya sehubungan dengan pekerjaannya dalam membuat akta tersebut, meliputi kebenaran materiil atas akta yang dibuatnya (Anshori, 2010) yakni:

1. Tanggung jawab notaris secara perdata terhadap kebenaran materiil terhadap akta yang dibuatnya.

2. Tanggung jawab notaris secara pidana terhadap kebenaran materiil dalam akta yang dibuatnya.

3. Tanggung jawab notaris berdasarkan Peraturan Jabatan Notaris terhadap kebenaran materiil dalam akta yang dibuatnya. 
Dalam penjelasan UUJN No.30 Tahun 2004 diterangkan pentingnya profesi notaris yakni terkait dengan pembuatan akta otentik. Pembuatan akta otentik ada yang diharuskan oleh peraturan perundang-undangan dalam rangka kepastian, ketertiban dan perlindungan hukum. Selain akta otentik yang dibuat oleh atau di hadapan notaris, bukan saja karena diharuskan oleh peraturan perundangundangan, tetapi juga karena dikehendaki oleh pihak yang berkepentingan untuk memastikan hak dan kewajiban para pihak demi kepastian, ketertiban, dan perlindungan hukum bagi pihak yang berkepentingan sekaligus bagi masyarakat secara keseluruhan (Anshori, 2010).

Ada dua mazhab notaris dunia yakni Notaris Latin dan Notaris Anglo Saxon (Pengurus Pusat Ikatan Notaris Indonesia, 2008). Notaris Anglo Saxon hakikatnya adalah pejabat hukum umum yang professional (private legal professional), seperti pengacara yang juga mempersiapkan dokumen atas nama para pihak dan memastikan dokumen telah sesuai undang-undang dan peraturan yang berlaku. Dipilih dari warga masyarakat yang mempunyai integritas dan moral yang tinggi. Diadopsi oleh Negara yang mengmut sistem Hukum Kasus (Common Law System). Hukum Sipil mengacu pada hukum Romawi (Italia Utara) yang meletakkan segala sesuatunya pada perundang-undangan. Adapun Notaris Latin adalah profesional hukUJ.11 seperti pengacara yang juga mempersiapkan dokumen atas nama kedua belah pihak dalam transaksi dan memastikan bahwa dokumen-dokumen ini memenuhi persyaratan hukum dari yurisdiksi yang sesuai (Thaw, 2000).

Indonesia menganut mazhab Notaris Latin. Notaris di Indonesia memberikan legal advice kepada para pihak sepanjang tidak bertentangan dengan undang-undang yang berlaku, ketertiban, dan kesusilaan. Tidak seperti notaris di Amerika Serikat yang hanya bertanggung jawab terhadap akurasi dan legalitas isi perjanjian akta (Pengurus Pusat Ikatan Notaris Indonesia, 2008).

Di dalam Pasal1868 KUHPerdata hanya menerangkan apa yang dinamakan akta otentik, akan tetapi tidak menjelaskan tempat dimana ia berwenang sedemikian, sampai dimana batas-batas wewenangnya dan bagaimana bentuk menurut hukum yang dimaksud, sehingga pembuat undang-undang masih harus membuat peraturan perundang-undangan untuk mengatur hal-hal tersebut, satu dan lain diatur dalam peraturan jabatan notaris, sehingga dengan demikian dapat dikatakan bahwa peraturan Jabatan notaris adalah merupakan peraturan pe- laksanaan dari Pasal1868 KUHPerdata, Notarislah yang dimaksud dengan Pejabat Umum itu (Sjaifurrachman dan Adjie, 2011).

Adapun kewenangan Notaris menurut pasal 15 UUJN No. 30 Tahun 2004, adalah:

1. Notaris berwenang membuat akta otentik mengenai semua perbuatan, perjanjian, dan ketetapan yang diharuskan oleh peraturan perundang-undangan dan/atau yang dikehendaki oleh yang berkepentingan untuk dinyatakan dalam akta otentik, menjamin kepastian tanggal pembuatan akta, menyimpan akta, memberikan grosse, salinan dan kutipan akta, semuanya itu sepanjang pembuatan akta-akta itu tidak juga ditugaskan atau dikecualikan kepada pejabat lain atau orang lain yang ditetapkan oleh Ih"Idang-undang.

2. Notaris berwenang pula:

i. Mengesahkan tanda tangan dan menetapkan kepastian tanggal surat di bawah tangan dengan mendaftar dalam buku khusus;

ii. Membukukan surat-surat di bawah tangan dengan mendaftar dalam buku khusus;

iii. Membuat kopi dari asli surat-surat di bawah tangan berupa salinan yang memuat uraian sebagaimana ditulis dan digambarkan dalam surat yang bersangkutan;

iv. Melakukan pengesahan kecocokan fotokopi dengan surat aslinya;

v. Memberikan penyuluhan hukum sehubungan dengan pembuatan akta;

vi. Membuat akta yang berkaitan dengan pertanahan; atau

vii.Membuat akta risalah lelang.

3. Selain kewenangan sebagaimana dimaksud pada ayat (1) dan ayat (2), Notaris mempunyai kewenangan lain yang diatur dalam peraturan perundang-undangan.

Undang-Undang Jabatan Notaris (UUJN) dan Peraturan Jabatan Notaris (PJN) memiliki esensi yang sama tentang notaris yakni sebagai pejabat umum yang berwenang membuat akta. Terminologi berwenang (bevoegd) dalam PJN maupun UUJN diperlukan karena berhubungan dengan ketentuan Pasal 1868 KUHPerdata yang menyatakan bahwa suatu akta otentik adalah yang sedemikian, yang dibuat dalam bentuk yang ditentukan oleh undangundang oleh-atau di hadapan pejabat umum yang berwenang untuk itu, ditempat akta itu dibuat. Untuk pelaksanaan Pasal 1868 KUHPerdata tersebut pembuat undang-undang harus membuat peraturan perundang-undangan untuk menunjuk para pejabat umum yang berwenang untuk membuat akta 
otentik dan oleh karena itulah para notaris ditunjuk sebagai pejabat yang sedemikian berdasarkan PJN maupun UUJN (robing, 1992).

Dalam kenotariatanfiduciary duty merupakan "suatu kewajiban yang ditetapkan undang-undang bagi seseorang yang memanfaatkan seseorang lain, dimana kepentingan pribadi seseorang yang diurus oleh pribadi lainnya, yang sifatnya hanya hubungan atas-bawahan sesaat. Orang yang mempunyai kewajiban ini harus melaksanakannya berdasarkan suatu standar dari kewajiban (standar of duty) yang paling tinggi sesuai dengan yang dinyatakan dalam hukum" (Hasibuan, 2010).

\section{Metodologi Penelitian}

Penelitian ini merupakan penelitian hukum normatif (doktrinal) berdasarkan data sekunder. Menurut Soemitro (1994), penelitian hukum normatif atau penelitian hukum doktrinal condong bersifat kualitatif dan berdasarkan data sekunder. Metode ini digunakan untuk melakukan analisis terhadap peraturan perundang-undangan, maupun kontrakkontrak. Sedangkan penelitian doktrinal digunakan untuk melakukan analisis terhadap asas hukumasas hukum (kontrak), literatur hukum, pandanganpandangan para sarjana hukum yang mempunyai kualifikasi tinggi (doktrin) (Marzuki, 2001).

Dalam penelitian hukum menurut Hemoko (2011) diperlukan metode pendekatan yang dimaksudkan untuk mendapatkan informasi dari berbagai aspek mengenai isu hukum yang sedang dicoba untuk dicari jawabannya. Pendekatan yang digunakan untuk menganalisis permasalahan dalam penelitian ini meliputi: (a) pendekatan Konseptual (conceptual approach); (b) pendekatan Undang-Undang (statute approach). Untuk pendekatan Undang-Undang, terutama difokuskan pada ketentuan BW yang berlaku di Indonesia; (c) pendekatan konseptual (conceptual approach) beranjak dari pendapat ahli (doktrin) yang terkait dengan materi hukum kontrak.

\section{Hasil Penelitian dan Pembahasan}

Pekerja seni dalam menjalin kerjasama dan melahirkan sebuah perjanjian/kontrak kerja lebih dilandasi pada rasa saling percaya, perjanjian/kontrak umumnya tidak dibuat dalam bentuk tertulis baik berupa akta dibawah tangan atau akta otentik. Terhadap hal tersebut sulit dirubah, menurut pekerja seni yang penulis wawancara. Banyak faktor sebagai penyebab, faktor dari luar dan/atau faktor dari dalam diri pekerja seni yang bersangkutan. Dalam kesimpulan pekerja seni yang disampaikan kepada penulis, me- reka merasa sulit dan/atau tidak akan bisa melakukan perubahan terhadap cara yang sejak lama telah pekerja seni gunakan. Kebiasaan yang dibangun pekerja seni tersebut di atas, menurut penulis bukanlah suatu cara yang buruk, apabila rasa saling percaya bisa dijaga secara timbal balik, memenuhi unsur-unsur asas itikad baik (togoe dentrow) yang terdapat dalam Pasal 1338 ayat (3) KUHPerdata (Nurmawati, 2009).

Asas itikad baik akan menjadi dasar untuk menilai apakah perjanjian yang terbentuk memenuhi kepatutan dan kesusilaan serta tidak menciderai sikap batin para pihak di dalamnya. Pekerja seni menyampaikan bahwa pada dasamya banyak persoalan yang mereka alami dalam membuat suatu perjanjian/kontrak, karena rasa percaya diberikan pada dasamya hanya wujud keterpaksaan, pekerja seni tidak ada pilihan lain. Sering terjadi wanprestasi atas hak yang seharusnya d'terima pekerja seni sesuai yang telah disepakati dan dibuat dalam bentuk akta dibawah tangan.Apabila tidak bersedia menjalani proses yang ditetapkan, berarti menghilangkan kesempatan untuk memperoleh pekerjaan, yang berakibat pekerja seni akan kehilangan pendapatan untuk pribadi dan/atau perkumpulan. Sebuah pilihan yang tidak populer apabila pekerja seni bersitegang untuk keluar dari kebiasaan tersebut.

Membuat konsep perjanjian/kontrak antara pekerja seni dengan pihak yang akan menggunakan jasa keahliannya tidak melakukan proses negosiasi secara rinci terlebih dahulu. Dalam proses yang sering dilakukan, pekerja seni diberi deskripsi pekerjaan beserta total nominal yang akan diperoleh atas prestasi yang dikehendaki, kemudian diminta menandatangani surat perjanjian yang telah disiapkan oleh pihak pengguna jasa. Pekerja seni dalam posisi harus menerima isi perjanjian itu, apabila perjanjian/kontrak kerja tersebut akan dilanjutkan. Hal seperti itu terus berlangsung tanpa ada keberanian dari pekerja seni untuk merubahnya.

Kondisi di atas menurut penulis sudah keluar dari tujuan asas keseimbangan, sesuai dengan pendapat Hemoko (2011) bahwa tujuan asas keseimbangan adalah "keseimbangan dalam menentukan hak dan kewajiban". Uraian Sudikno dalam Hasibuan (2011) tentang teori klasik, bahwa "kontrak merupakan perbuatan hukum yang meliputi penawaran dari pihak yang satu dan penerimaan dari pihak lain yang didasarkan pada kata sepakat". Apabila kondisi pekerja seni bertolak belakang dengan pengertian kedua teori tersebut di atas terus berjalan sesuai dengan pendapat Budiono \{2006) "bisa terjadi situasi 
abnormal". Berdasarkan pendapat tiga ahli hukum di atas, dari hasil pengumpulan bahan hukum primer dan bahan hokum sekunder, indikasi abnormal terlihat jelas di dalam proses melahirkan suatu perjanjian. Pihak terkait dalam melakukan kontrak kerja dengan pekerja seni memiliki posisi tawar Iebih besar. Hal itu bisa terjadi karena pekerja seni umumnya belum mapan untuk bergerak sendiri dan/atau secara berkelompok melakukan pagelaran hasil karyanya. Pihak terkait dalam suatu perjanjian/kontrak umumnya pemilik akses yang kuat terhadap sarana/ ternpat yang dibutuhkan pekerja seni menampilkan hasil karyanya. Hal tersebut membuat pekerja seni dalam kesadaran dan terpaksa sepakat atas ketidaksepakatan tentang isi perjanjian/ kontrak yang sudah mereka tentukan. Kondisi seperti itu sebenamya sudah terjadi pelanggaran atas asas keseimbangan (evenwichts beginsel).

Berdasarkan pendapat Hemoko (2011) tentang hakikat merancang kontrak, bahwa dalam suatu kontrak minimal terkait dua pihak yang saling berkehendak terjadinya suatu prestasi timbal batik atas suatu keadaan yang mereka inginkan terjadi. Kesepakatan kedua pihak dilandasi asas kebebasan berkontrak. Prestasi timbal balik antara pihak yang kcmudian disepakati melahirkan suatu perjanjian, memperoleh sanksi hukum apabila terjadi wansprestasi oleh satu pihak terhadap pihak lainnya.

Pasal 1338 Kii:ab Undang-Undang Hukum Perdata (KUHPerdata) menetapkan bahwa: "semua perjajian yang dibuat secara sah berlaku sebagai undangundang bagi mereka yang membuatnya." Dalam pengertian, pihak terkait membuat norma hukum yang mereka sepakati untuk masing-masing pihak menjalankan sesuai hak dan kewajibannya. Dan Pasal1320 KUHPerdata menjelaskan untuk sahnya suatu perjanjian diperlukan empat syarat:sepakat mereka yang mengikatkan dirinya, kecakapan untuk membuat suatu perikatan, suatu hal tertentu, suatu sebab yang halal.

Menurut Budiono (2006) aspek "isi kontrak" berkaitan dengan asas kebebasan berkontrak. Hal ini dikarenakan setiap pihak memiliki kebutuhan yang berbeda atas objek yang diperjanjikan untuk diwujudkan. Budiono (2006) menyatakan bahwa secara tegas cakupan asas kebebasan berkontrak dibatasi oleh undang-undang, memberi kemungkinan absah, batal demi hukum atau kadang dapat dibatalkan. Berdasarkan pendapat Budiono (2006) tersebut, setiap pihak hendaknya memiliki pengetahuan tentang hal-hal yang dibolehkan serta yang tidak dibenarkan oleh peraturan perundang-undangan yang berlaku dan berlandaskan asas hukum kontrak Indonesia dalam setiap pembuatan kontrak.

Berdasarkan penelitian terhadap perjanjian/kontrak dalam bentuk tertulis yang dibuat antara pekerja seni dengan pihak yang memakai jasanya, perjanjian kurang memenuhi unsur dasar kontrak, yang secara jelas. lsi perjanjian/kontrak yang dibuat dalam bentuk tertulis itu, lebih mengutamakan kepentingan satu pihak (pemakai jasa pekerja seni). Pihak pekerja seni sebagai pihak yang harus menerima. Kondisi tersebut sudah berlangsung lama, pekerja seni tidak mampu melindungi harapan wajar dari adanya perjanjian/kontrak, bahkan sering terjadi pengayaan satu pihak dengan tidak memperdulikan kebutuhan pekerja seni dalam melakukan prestasi dan/atau pemenuhan keperluan dasar untuk pribadi/kelompok sesuai yang sudah disepakati dan diperjanjikan. Situasi tersebut berdasarkan hasil wawancara terhadap pekerja seni, bisa terjadi karena pekerja seni dalam kondisi sebagai pihak yang sangat membutuhkan kesempatan/pekerjaan yang diperjanjikan untuk kelangsungan dunia seni dalam berkarya dan sekaligus kebutuhan hidup pribadi yang terlibat di dalamnya.

Apabila cara/teknik hukum mereka tempuh dalam proses membuat perjanjian/ kontrak, maka bisa mengakibatkan pemakai jasa beralih kepada pekerja seni lain untuk melakukan prestasi yang mereka inginkan dari pekerja seni. Hal tersebut diungkapkan pekerja seni dalam wawancara dengan penulis. Mempelajari bahan hukum berupa berkas perjanjian yang dibuat pekerja seni dengan pihak terkait, belum ditemukan profesi notaris berperan di dalamnya. Tidak ada satupun dibuat dalam bentuk akta notaris (akta otentik). Semua dibuat berbentuk akta dibawah tangan, dan tanpa adanya pihak yang bersaksi.

Pekerja seni umumnya kurang mengetahui perbedaan dan kegunaan antara akta dibawah dengan akta otentik. Ketidaktahuan tersebut mengakibatkan pekerja seni sudah merasa cukup memiliki perjanjian dalam bentuk perjanjian dibawah tangan. Perjanjian dibawah tangan yang dibuat dengan pihak terkait oleh pekerja seni hanya sebagai formalitas saja, cialam implementasinya sering tidak bisa menjadi landasan untuk memperoleh hak-hak yang telah diperjanjikan dan disepakati kedua pihak terkait. Dengan sadar pekerja seni tidak berusaha mempermasalahkan tindakan wanprestasi yang dilakukan pihak terkait dalam kontrak. 
Dalam upaya meningkatkan pengetahuan hukum pekerja seni dalam pembuatan perjanjian/kontrak komersial, berdasarkan Perundang-Undangan yang berlaku:

1. Notaris menjalankan profesi dalam pelayanan hukum sesuai kewenangan berdasarkan Pasal 15 angka (2) huruf (e), yaitu "memberikan penyuluhan hukum sehubungan dengan pembuatan akta."

2. Konsideran Undang-Undang Jabatan Notaris (UUJN) RI No. 30 Tahun 2004 Tentang Jabatan Notaris huruf (a) menyatakan bahwa: "Negara Republik Indonesia sebagai negara hukum berdasarkan Pancasila dan Undang-Undang Dasar (UUD) Negara Republik Indonesia Tahun 1945 menjamin kepastian, ketertiban, dan perlindungan hukum, yang berintikan kebenaran dan keadilan." Dalam huruf (b) dinyatakan bahwa: "untuk menjamin kepastian, ketertiban, dan perlindungan hukum, dibutuhkan alat bukti tertulis yang bersifat otentik mengenai keadaan, peristiwa atau perbuatan hukum yang diselenggarakan melalui jabatan tertentu. Yang dimaksud jabatan tertentu itu, huruf (c) menyebutkan "notaris yang menjalankan profesi dalam pelayanan hukum kepada masyarakat" dan huruf (d) menyatakan bahwa "jasa notaris dalam proses pembangunan makin meningkat sebagai salah satu kebutuhan masyarakat."

3. Berdasarkan uraikan konsideran Undang-Undang Jabatan Notaris tersebut, menurut Asshiddiqie (2008) bahwa, "disamping pembuatan hukum (law making) dan penegakan hukum (law enforcing) diperlukan kegiatan pemasyarakatan hukum (law socialization). Sosialisasi hukum, perangkat pelaksana serta fungsinya, menurut penulissuatu langkah yang harus dilakukan oleh Negara melalui lembaga terkait untuk membantu masyarakat mengetahui langkah-langkah hukum apa yang harus ditempuh dan lembaga apa yang harus mereka datangi sehubungan aktivitas sosial mereka yang berimplikasi hukum. Langkah tersebut seharusnya dilaksanakan oleh Negara di semua lapisan masyarakat, karena dalam penelitian penulis temukan bahwa ketidaktahuan tentang profesi dan jabatan notaris ternyata juga terdapat di lingkungan yang sudah memiliki akses lebih banyak untuk mengetahui suatu hal. Bagaimana dengan masyarakat Indonesia lainnya yang berada jauh dari pusat pusat informasi dan tidak memiliki fasilitas teknologi untuk bisa mencari tau sendiri tentang perkembangan hukum positif Indonesia?.
4. Notaris menjalankan kewajiban sesuai Pasal16 angka (1) huruf (a) Undang-Undang Jabatan Notaris (UUJN) No.30 Tahun 2004 yaitu, "berkewajiban bertindak jujur, seksama,mandiri, tidak berpihak, dan menjaga kepentingan pihak yang terkait dalam perbuatan hukum.

Pekerja seni yang menggunakan jasa profesi notaris akan terjaga kepentingannya terhadap pihak terkait dalam perjanjian untuk mendapatkan haknya sesuai yang sudah disepakati dan diperjanjikan. Pelaku seni dalam wawancara dengan penulis menyatakan sering dalam posisi lemah-sering tidak dapat memperoleh hak yang sudah disepakati dan dituangkan dalam perjanjian dibawah tangan.

Menurut Kie (2007) bahwa masyarakat (pekerja seni) membutuhkan figur yang dapat dipercaya, tanda tangan dan segelnya memberi jaminan di hari mendatang apabila t:!rjadi sengketa atas isi akta yang mereka kehendaki. Undang-Undang Jabatan Notaris (UUJN) No.30 Tahun 2004 sebagai penjabaran atas Pasal 1868 Kitab Undang-Undang Hukum Perdata menjelaskan dalam Pasal1 angka (1), bahwa notaris adalah pejabat umum yang berwenang untuk membuat akta otentik dan hal tersebut memberi pengertian yang sama atas arti pentingnya profesi notaris (Anshori, 2010).

\section{Kesimpulan}

Pengetahuan tentang hukum perjanjian/kontrak secara pribadi/bersama-sama/ organisasi, mampu membuat perjanjian/kontrak yang memiliki landasan hukum yang kuat, sehingga pekerja seni akan memp2roleh hak-haknya secara profesional. Pengetahuan tentang profesi dan jabatan notaris, berdasarkan Undang-Undang Jabatan Notaris (UUJN) No.30 Tahun 2004 memiliki kewenangan dan kewajiban yang dapat membantu pekerja seni menambah pengetahuan hukum tentang pembuatan akta. Dengan kedudukan dan fungsi Notaris kepada masyarakat luas dan khususnya pekerja seni, sebagai pejabat umum yang dapat membantu melahirkan kontrak-kontrak berbentuk akta otentik yang berkualitas dalam rangka meningkatkan pengetahuan masyarakat pada aspek-aspek hukum dalam suatu perjanjian, secara langsung ataupun tidak langsung berdampak positif untuk menumbuhkan kesadaran hukum masyarakat Indonesia membuat kontrakkontrak kerjasama dalam negeri maupun dengan pihak luar negeri dalam bentuk akta otentik yang dapat meningkatkan kualitas hidup bangsa secara sosial dan perekonomian. 


\section{Referensi}

Andasasmita, Komar. (1990) Notaris II-Contoh Akta Otentik dan Penjelasannya, Bandung: Ikatan Notaris Indonesia Daerah Jawa Barat.

Anshori, Abdul Ghofur (2010) Lembaga Kenotariatan Indonesia Perspektif Hukum dan Etika. Yogyakarta:UII Press.

Asshiddiqie, Jimly (2008) Menuju Negara Hukum yang Demokratis.Jakarta: PT. Bhuana llmu Popular.

Budiono, Herlien. (2006) Asas Keseimbangan bagi Hukum Perjanjian Indonesia-Hukum Perjanjian BerIandaskan Asas-Asas wigati Indonesia. Bandung: PT. Citra Aditya Bakti.

Dewi, Santia dan R.M. Fauwas Diraja. (2011).Panduan Teori dan Praktik Notaris. Yogyakarta:Pustaka Yustisia.

Hasibuan, Fauzie Yusuf. (2010) Keseimbangan dan Keterbukaan dalam Kontrak Anjak Piutang di Indonesia.Jakarta:Fauzie dan Partners.

Hemoko, Agus Yuda, (2011) Hukum Perjanjian-Asas Proporsionalitas dalam Kontrak Komersial. Jakarta:Kencana Prenada Media Group.

Kie, Tan Thong. (2007) Studi Notariat \& Serba-Serbi Praktek Notaris. Jakarta: PT. Ichtiar Baru Van Hoeve.

Marzuki, Peter Mahmud. (2001) Penelitian Hukum, Yuridika. Vol.16, No.1.

Nurmawati, B., (2009) Hukum Kontrak Dalam Pelaksanaan Perjanjian Lisensi Paten. Jurnal IUS FACTI. Vol. 2. hh. 1-13.

Pengurus Pusat lkatan Notaris Indonesia. (2008) 100 Tahun Ikatan Notaris Indonesia Jati Diri Notaris Indonesia Dulu, Sekarang, dan Di Masa Datang. Jakarta: PT Gramedia Pustaka.

Sjaifurrachman dan Habib Adjie, (2011) Aspek Pertanggungjawaban Notaris dalam Pembuatan Akta.Jakarta:CV. Mandar Maju.

Soemitro, Ronny Hanitiko (1994). Metode Penelitian Hukum dan Jurumetri.Jakarta: UI Press.
Thaw, Deborah M. (2000) the Notary Public and its Impact in 21st Century, A Presentation at the NACO/NACRC Annual Conference.

Tobing, G.H.S. Lumban (1992) Peraturan Jabatan Notaris (Notaris Reglement). Jakarta: Erlangga. 